Tamara Bairašauskaitè, Prof. habil. $d r$.

Lithuanian Institute of History, Lithuania

\title{
CONSIDERATION OF THE PROJECT FOR THE ABOLITION OF SERFDOM AT THE DIETINE IN THE WILNO GOVERNORATE IN 1817
}

\section{DZIMTBŪŠANAS ATCELŠANAS PROJEKTA IZSKATİ̌̌ANA VIETĒJĀS MUIŽNIECİBAS KOPSAPULCẼ VIL,N̦AS GUBERN̦Ā 1817. GADĀ}

\begin{abstract}
Kopsavilkums
Aleksandra I lēmums par dzimtbūšanas atcelšanu Igaunijas, Kurzemes un Livonijas guberṇās laikā no 1817. līdz 1819. gadam veicināja Lietuvas muižniecību izteikt priekšlikumu atbrīvot zemniekus. Rakstā ir sniegta analīze par to, kā 1817. gadā Viḷnas provinces muižnieku kopsapulces pārstāvji apsvēra dzimtbūšanas atcelšanu. Apskatīti iemesli, kāpēc šis jautājums tika izvirzịts, tā iniciatori, sagatavošanās pirms šã jautājuma izskatī̌šnas diskusijām kopsapulcē, izskatī̌̌anas procesa gaita un rezultāti. Reformas atbalstītāji vēlējās atcelt dzimtbūšanu, tomēr nepiešķirot zemniekiem zemi. Tikmēr muižniecība lūdza Aleksandru I izveidot komisiju dzimtbūšanas atcelšanai Lietuvas guberņās. Tomēr atļauja tika atteikta, un reforma netika îstenota. Neraugoties uz to, muižniecíbas aptaujas rezultāti atklāja, ka Lietuvas muižniecība atbalstija dzimtbūšanas atcelšanu.

Atslēgvārdi: Lietuvas muižniecības kopsapulce, Mihaels Jozefs Rēmers, dzimtbūšanas atcelšana, muižkungu aptauja
\end{abstract}

\begin{abstract}
Summary
The decision taken by Alexander I to abolish serfdom in the governorates of Estonia, Courland and Livonia in 1817-1819 has encouraged the proposition of the Lithuanian nobility to emancipate unfree peasants. The article presents an analysis of how in 1817 the Wilno governorates dietine considered the issue of the abolition of serfdom. The reasons why this issue was raised, its initiators, the preparation ahead of discussions at the dietine, the course of the consideration process and its results are all discussed. Supporters of the Reform sought out to abolish serfdom however without granting land to peasants. Meanwhile, the nobility enquired Alexander I to establish a Commission for the preparation of abolition of serfdom in the Governorates of Lithuania. However, the permission refused and the Reform was not implemented. Nevertheless, the results of a survey of the nobility revealed that Lithuanian nobility supported the abolition of serfdom.
\end{abstract}

Keywords: Lithuanian nobility's dietine, Michał Józef Römer, abolition of serfdom, survey of manor lords

The aim of the article is to analyse how in 1817 the Lithuanian nobility, following the practices of the Wilno Governorate dietine, raised the question of the abolition of serfdom. In the general context of the history of Lithuanian nobility, the 1817 Wilno dietine remained an episode which did not bring major results. On the other hand, an 
attempt to abolish serfdom as early as in 1817 was an attestation of the reaction to the social changes which took place in the vicinity and a society on its way to modernity.

After the Third Partition of the Polish-Lithuanian Commonwealth (1795), the politically active noble elite had considered the necessity of abolishing serfdom in Lithuania. The liberation of the peasantry and their civil rights were discussed in the draft of the Constitution of the Grand Duchy of Lithuania (GDL), prepared by Ksawery Lubecki and Kazimierz Plater in 1811-1812. ${ }^{1}$ However, at this time the group of Lithuanian political elites, headed by Michał Kleof Ogiński, who spoke forth at the Saint Petersburg court, failed to implement this project. Lithuania did not receive autonomy, and the nobility had to be satisfied with the right to self-rule.

Nobility dietines took place every three years, where district and governorate nobility leaders, court chairmen and judges were elected, members and secretaries of nobility deputations were chosen. Additionally, they deliberated tax issues, local budgets and other matters of importance to the nobility's estate. In the first half of the $19^{\text {th }}$ century, Lithuania's nobility actively exercised their right to submit requests to the Russian emperor on how they wanted the court system to change, how its procedures could be altered, and how local economic, social and cultural problems could be resolved. Among these rights was the opportunity to express their requests (dezyderaty) and present them to the highest imperial seat of power. The request to grant their own peasants freedom would have been a realisation of this right.

The real inspiration to start speaking about the liberation of the Lithuanian peasantry in 1817 specifically was the approval expressed by Alexander I regarding the abolition of serfdom in the Baltic governorates. Serfdom was abolished with the decree of May 23, 1816 in the Governorate of Estonia, while the "Regulations on the Peasants in the Governorate of Courland" were confirmed with the decree of August 25,1817 . The peasants were given personal freedom, the right to acquire land, and to belong to the jurisdiction of state and local institutions. Following the regulations, an interim period had been foreseen in order to manage interactions between landed nobility, the state and freed peasants. The regulations also set the conditions under which peasants were to be freed. ${ }^{2}$

The agricultural policies of Alexander I in the neighbouring governorates appeared as a good chance for the nobility from Lithuania's governorates to seek similar social reforms in their own land. Regular nobility dietines were meant to be held in the Governorate of Wilno in late 1817 (dietines in the governorates of Hrodno and Minsk were meant to start somewhat later) - these dietines were the only legal forum permitted to the nobility, where the consideration of similar questions could proceed.

There is no doubt that advance preparations were made for this dietine. It is unlikely that the local nobility, who had just warmed up to the imperial self-rule institution that could satisfy their ambitions to hold elected posts, would have thought of the idea of releasing their serfs. Higher-ranked figures would have played a part in

1 Sirutavičius V. Konstituciniai sumanymai Lietuvoje XIX a. pradžioje. In: Lietuvos valstybès idejja (XIX a. - XX a. pradžia). Lietuvių atgimimo istorijos studijos, t. 3, Vilnius: Žaltvykslè, 1991, pp. 9, 21-22.

2 Полное собрание законов Российской империи, собр. 1, т. 33, № 26 277, т. 34, № 27024 . All dates in the article are according to the Julian calendar. 
raising this idea, - those, who had a closer vantage point for observing the domestic policy directions taken by Alexander I.

According to Janulaitis, the consideration of the abolition of serfdom was indirectly initiated by the Wilno deputy governor, Michał Plater-Zyberk. Plater-Zyberk suggested to his relative, K. Plater, who, as mentioned before, prepared the draft for the Constitution of the GDL, that this idea should be discussed at the Wilkomierz district dietine, and later on transferred to the governorate dietine. K. Plater owned the large Dusiaty Estate in the Wiłkomierz district, thus, he was an influential figure in this governorate. It appears that the deputy governor's idea was also approved by the politicians Adam Jerzy Czartoryski and senator Seweryn Potocki, who resided in Saint Petersburg. ${ }^{3}$ The senator M. K. Ogiński also observed how events were unfolding at the time. These highly-ranked officials did not publicly interfere in the activities of the nobility's dietine.

It is not completely clear which position was taken by another author of the draft of the Constitution of the GDL - the rising political star, K. Lubecki. In 1816, he was appointed as the Wilno civil governor, yet he did not carry out these duties, instead spending more time in Warsaw, participating in various commissions. Subsequently, he went on to become the minister of finance in the Kingdom of Poland. Lubecki's biographer, historian Stanisław Smolka, failed to find evidence that this politician supported the abolition of serfdom. ${ }^{4}$

In one way or another, the Witkomierz district dietine took upon itself the role of initiator and prepared instructions, signed by K. Plater, for its delegates to the governorate dietine. There is a shortage of evidence to claim that he was the only author of the instructions. They consisted of sixteen points, three of which were dedicated to the peasantry. Regardless of the uplifting style of the instructions and the panegyrics to the monarch, the Wilkomierz district's nobles clearly spoke in favour of granting more rights and freedoms to the peasants: "This large part of society, which through its manual labour and spilt blood gives the nation existence, joy and elevates it, is worthy of a better fate. The voice of enlightenment and humanity, one could say, the voice of nature, is calling that the time has come to appreciate these treasured beings $<\ldots\rangle$, who have since the time immemorial deserved our gratitude".

The Wilkomierz district nobility ordered their delegates to seek that the peasants in the Lithuanian governorates would be given the same freedoms as the peasantry in the governorates of Estonia, Courland and Livonia. To achieve this 'revered goal', the delegates had to ask the imperial government to form a commission consisting of representatives from all the districts, who cared about universal well-being, and who could prepare a project for the abolition of serfdom. They also formulated the principles based on which the peasants would be given freedom. Firstly, they had to

3 Janulaitis A. Baudžiavos panaikinimo sumanymai Lietuvoje (1817-1819 m.). Lapas iš socialinès Lietuvos istorijos. Kaunas: Lietuvos universiteto teisių fakultetas, 1929, p. 18.

4 Smolka S. Polityka Lubeckiego przed powstaniem listopadowem. Kraków: nakładem Akademii Umiejętności, 1907, t. 1, s. 70 .

$5 \quad$ Druki dotyczące organizacji i przebiegu sejmików szlacheckich guberni litewsko-wileńskiej, 18141820. Biblioteka Narodowa w Warszawie, Archiwum Romerów (henceforth - BN AR), IV. 8671, k. 8. 
ensure that the economy of the estates would not suffer as a result of the reform. Secondly, to abolish the responsibility of landowners to compile lists of village residents, and thirdly, to regulate the economic and legal relations of villages and estates. In addition, the nobility ordered their delegates to seek that schools be established in all parishes and private towns for the peasantry, where they could receive an elementary education. ${ }^{6}$ No mention was made of peasants' rights to own land or the possibility to obtain it.

On December 1, 1817, governorate and district nobility leaders and ten delegates from each district (the Governorate of Wilno consisted of eleven districts) gathered at the Wilno governorate dietine. Each participant complied with the set property qualification, owned land, and most owned peasants, as well. The dietine was chaired by the leader of the governorate's nobility, Teodor Ropp. The meetings went on for three weeks, and did not greatly differ from the usual routine. The nobility's leader presented his activity report for the last period of tenure, and new governorate court chairmen and judges were elected, as were the officials of nobility's self-ruling institutions. The famous lawyer Michał Józef Römer was elected as the new leader of the governorate's nobility. After the elections, those gathered would usually leave, only the commissions would remain in Wilno, having to allocate taxes and prepare a summary of the district dietine's requests to be sent to the governorate's government. ${ }^{7}$

However, this time the dietine's work took a different course. On December 21, when the secretary of the nobility's deputies meeting had just been elected, Szymon Zawisza, the leader of the Upita district nobility, appealed to the dietine. He gave a long speech, reminding those gathered of man's natural rights, and how the Constitution of Poland of May 3, 1791 had resolved the question of serfdom, and urged the nobles to follow the example of Europe, to renounce the nobility's privilege of having serfs, giving them freedom to freely choose the place of residence, as well as a landowner with whom they could negotiate the terms and conditions of the use of a land. Zawisza suggested asking the emperor to allow the Lithuanian nobility to form a commission that would prepare a project for the abolition of serfdom to benefit all of the land's population. ${ }^{8}$

Zawisza's speech demonstrated that not just the nobility from Wiłkomierz but those from other districts also had come prepared to discuss the question of freeing the serfs. The opposition - major landowners - also came ready, presenting their spokesman. They chose a figure who was not particularly well known - the Oszmiana district delegate, Michał Paszkowski. During the entire dietine, he did not say a word, but on this occasion, he spoke as if he had a speech prepared in advance. Paszkowski claimed that the district delegates were not authorised to debate this matter. In addition, it was not known just how the experiment in Estonia and Courland would develop, which was why there was no reason for Lithuania to rush in. First of all, the nobility had to be asked whether they would agree to set their serfs free, and to

\footnotetext{
Ibid., k. 8v.

Diariusz czynności elekcyjnej. Ibid., IV. 8669, k. 1-36.

8 Ibid., k. 35v; Mościcki H. Sprawa włościańska na Litwie w pierwszej ćwierci XIX stulecia. Warszawa: nakład Gebethnera i Wolffa, 1908, pp. 24-26; Janulaitis A. Op. cit., p. 22, 79.
} 
discuss the conditions for freeing serfs so that the land would not suffer and the action result in unrest. In his view, the European example would not suit Lithuania either, as the ideas of freedom, equality, liberalism, education and philanthropy had brought it numerous problems. He recommended first asking the emperor, and then, with his approval, to pass the issue of the abolition of serfdom on to the major landowners. ${ }^{9}$

The nobility allocated several days to discussing the liberation of the peasantry. The dietine did not convene on December 22, but the next day, talks escalated. The dietine protocol shows that around one third of the delegates had already left for their homes, but there were still quite many who wished to speak. The surnames of those who spoke were indicated in the protocol, but the content of what they said was not mentioned, and thus the speakers' opinions are not known to us.

However, we do know that the notice of K. Plater, who was not present, was read at the dietine, encouraging the nobility to abolish serfdom, while the Brasław and Zawilejski district dietines wrote up instructions for their delegates, ordering them to back the liberation of the peasantry. The Wiłkomierz district dietine instructions were printed and distributed in the city.

According to historians, only the opposition's representative, Paszkowski, spoke publicly against the abolition of serfdom, saying so in another speech. This time he urged not to rush into reforms, and to preserve the right of the nobility to have serfs, as this was the only way of guaranteeing that order was maintained in society. ${ }^{10}$ That day, the dietine did not reach a decision and decided to wait until the commission completed its work writing up all the requests submitted by nobles from the districts.

The dietine delegates who had stayed on in Wilno gathered on December 30 to hear the commission's results and to elect a delegation that would present the requests of the Wilno governorate nobility to the emperor. a large crowd of general public had also entered the meeting hall, including university students, burghers and peasants. The delegates argued again over the abolition of serfdom, as the final decision had to be reached on whether the Wilno governorate's nobility would request the abolition of serfdom. Paszkowski exclaimed that the dietine delegates were not unanimous on this issue, only three districts had prepared instructions for their delegates, and some delegates opted out of discussing the matter altogether. Paszkowski himself was not authorised to support the liberation of the peasantry, and, as a loyal subject of the emperor, he was not going to topple the established order, which was just and proper. ${ }^{11}$

The gathered public reacted loudly to Paszkowski's speech, interrupting the speaker with their shouts and cries. Amid the jostling, someone attached a card with the word 'gallows' to his back. Once he had finished his speech, he left the hall and rushed to lodge a complaint with the governorate government about the indignity he experienced as a delegate, and about the threats made on his life. ${ }^{12}$ While the government reacted and ordered the dietine dismissed, the delegates still managed

9 Materiały dotyczące wystąpienia zgromadzenia szlacheckiego guberni litewsko-wileńskiej do cesarza z petycją o zezwolenie na zajęcie się sprawą polepszenia bytu włościan. BN AR, IV. 8672, k. 8-10.

10 Janulaitis A. Op. cit., p. 28.

11 BN AR, IV. 8672, k. 13-14.

12 Janulaitis A. Op. cit., p. 31. 
to approve all the points from the nobility's requests, including the request to form a commission that would prepare recommendations for the liberation of the peasantry. They also found time to elect a delegation that had to present these requests to Alexander I when he would stop in Wilno on his way to Warsaw. The delegates of several districts assembled again on January 3 and 5, 1818. They did not approve of the Troki district delegate's suggestion to utilise the authority of the elites and include M. K. Ogiński and A. J. Czartoryski, as well as other influential figures in the delegation. They also listened to the reproaches made by the deputy governor M. Plater-Zyberk against the leader of the governorate's nobility T. Ropp, because he lost control of the dietine meetings, had allowed outsiders into the hall and had failed to manage the riots or stop the agitation over liberation of the peasantry. ${ }^{13}$

News about the wishes of the Wilno governorate's nobility to liberate the peasants reached Alexander I from elsewhere, not the elected delegation. He found out about it from the reports of the Wilno governor-general Alexander Rimski-Korsakov and the deputy governor M. Plater-Zyberk, where they excused themselves for the rather disruptive dietine. The highly-ranked officials assured the emperor that the nobility was only trying to approve the emperor's internal policies and to follow his example. ${ }^{14}$

Alexander I had a somewhat different assessment of the situation. On April 17, 1818, he wrote to Rimski-Korsakov from Warsaw, saying that he was not pleased with the events that unfolded at the Wilno governorate dietine. The emperor did not deny that the "nobility were guided by noble-minded and humane motives", however, in his view, they had "overstepped the limits of moderation, discretion and laws". ${ }^{15}$ The governorate's government was also condemned for surrendering to the nobility and for not keeping order. Regarding the liberation of the peasantry, the emperor only briefly mentioned he would change the old ways but would not want to do this without first asking for society's opinion. He asked the Wilno governor-general to ask the nobility whether they truly all wanted a commission to be established that would make recommendations on how to improve the life of the peasantry.

Organising the survey of the nobility became the responsibility of the newly-elected leader of the Wilno governorate's nobles, M. J. Römer. At the end of May, 1818, he sent out two secret circulars to the district nobility leaders. In one circular, he explained why the survey was necessary and included the form. The other circular had instructions on how to collect information, so that no undesirable rumours would spread about the freedom of the peasantry and lead to unrest. He also suggested that the task of conducting the survey should not be given to the police, but instead to loyal people, such as a landowner who could collect the manor lords' signatures. ${ }^{16}$

The survey results showed that the average Lithuanian manor lord was not unfamiliar with a modern world view. There were 1460 manor lords who voted in favour

13 BN AR, IV. 8672, k. 1-2.

4 Janulaitis A. Op. cit., p. 42.

15 Аело об учрежАении комиссии по облегчению быта крепостных крестьян. Аокументы по деку Ошмянского предводитемя Аворянства Пашковского, 1817-1820. Lithuanian State Historical Archives (henceforth - LSHA), col. 391, inv. 9, file 2483, p. 47.

16 Ibid., 1. 56, 61. 
of the abolition of serfdom, who had a total of 116647 serfs under their control, whereas 80 manor lords who owned 6032 serfs voted against. ${ }^{17}$ Nevertheless, Alexander I was no longer interested in the results.

In 1818-1820, M. J. Römer several times tried to have the emperor receive a delegation of nobles from the Governorate of Wilno to hear out their requests. As he never received an invitation for an audience, M. J. Römer concluded that "it would not be appropriate for us to speak on this matter any more". ${ }^{18}$ Alexander I never mentioned the possibility of abolishing serfdom in the Lithuanian governorates ever again, although he did allow this in the Governorate of Livonia in 1819.

\section{Conclusions}

In the second decade of the $19^{\text {th }}$ century, the Lithuanian nobility were not prepared to take on the responsibility for social reforms in their land. They were open to the liberal ideas that were spreading at the time, nevertheless, the archival documents on 1817 the Wilno dietine reveal that Lithuanian nobility was not closely familiar with the "Regulations on the Peasants in the Governorate of Courland" of August 25,1817 . They did not hold an independent vision for the abolition of serfdom, and could not quite imagine how such reforms would work and what the outcomes could have been. They did support the idea to abolish peasants without providing them with an access to land, however, they did not propose any new ideas thereof. The Lithuanian nobility hoped that a free peasant would not cause them any inconvenience, as land was meant to remain the property of the manor lords, while those who did not own property were not concerned about the abolition of serfdom at all.

\section{BIBLIOGRAPHY}

\section{Literature}

1. Janulaitis A. Baudžiavos panaikinimo sumanymai Lietuvoje (1817-1819 m.). Lapas iš socialinès Lietuvos istorijos. Kaunas: Lietuvos universiteto teisių fakultetas, 1929.

2. Mościcki H. Sprawa włościańska na Litwie w pierwszej ćwierci XIX stulecia. Warszawa: nakład Gebethnera i Wolffa, 1908.

3. Sirutavičius V. Konstituciniai sumanymai Lietuvoje XIX a. pradžioje. In: Lietuvos valstybès idejja (XIX a. - XX a. pradžia). Lietuvių atgimimo istorijos studijos, t. 3, Vilnius: Žaltvykslè, 1991.

4. Smolka S. Polityka Lubeckiego przed powstaniem listopadowem. Kraków: nakładem Akademii Umiejętności, 1907, t. 1.

LSHA, col. 391, inv. 9, file 2483, p. 63.

18 Przemówienia Michała Römera na zgromadzeniu szlacheckim guberni litewsko-wileńskiej, BN AR. IV. 8670, 1. 1-2. 